\author{
UNIVERSIDADE DE SÃO PAULO \\ ESCOLA DE ENGENHARIA DE LORENA
}

\title{
DAIANA RODRIGUES TORRES
}

Aproveitamento do Hidrolisado da casca de mandioca como substrato para a produção de carotenoides por leveduras isoladas da Região Amazônica

Lorena

2019 


\section{DAIANA RODRIGUES TORRES}

Aproveitamento do Hidrolisado da casca de mandioca como substrato para a produção de carotenoides por leveduras isoladas da Região Amazônica

\footnotetext{
Tese apresentada à Escola de Engenharia de Lorena na Universidade de São Paulo para obtenção do título de Doutor em Ciências do Programa de Pós-Graduação em Biotecnologia Industrial na área de conversão de biomassa.

Orientadora: Prof ${ }^{a}$. Dr. Inês Conceição Roberto
}

Versão Original

Lorena 
Ficha catalográfica elaborada pelo Sistema Automatizado da Escola de Engenharia de Lorena, com os dados fornecidos pelo(a) autor(a)

Torres, Daiana Rodrigues

Aproveitamento do Hidrolisado da casca de mandioca como substrato para a produção de carotenoides por leveduras isoladas da Região

Amazônica / Daiana Rodrigues Torres; orientadora Inês Conceição Roberto - Versão Original. - Lorena, 2019. $194 \mathrm{p}$.

Tese (Doutorado em Ciências - Programa de Pós Graduação em Biotecnologia Industrial na Área de Conversão de Biomassa) - Escola de Engenharia de Lorena da Universidade de São Paulo. 2019

1. Leveduras. 2. Pigmentos carotenoides. 3. Casca de mandioca. 4. Vitamina a. 5. Anti-oxidante. I. Título. II. Roberto, Inês Conceição, orient. 


\section{RESUMO}

TORRES, D. R. Aproveitamento do Hidrolisado da casca de mandioca como substrato para a produção de carotenoides por leveduras isoladas da Região Amazônica. 2019. 174 p. Tese (Doutorado em Ciências) - Escola de Engenharia de Lorena, Universidade de São Paulo, Lorena, 2019.

O presente trabalho teve como objetivo 0 aproveitamento do hidrolisado de cascas de mandioca para produção de pigmentos carotenoides. Para isso, foi realizado o isolamento de leveduras provenientes da Região Amazônica, caracterização das cascas de mandioca e obtenção dos hidrolisados por via ácida $(\mathrm{HA})$ e enzimática (HE). Por fim, foram avaliados o efeito da relação C: $\mathrm{N}$ e da luminosidade sobre a produção de carotenoides pelas leveduras previamente selecionadas nos hidrolisados. Os extratos carotenogênicos foram caracterizados quanto ao potencial anti-oxidante e antimicrobiano, sendo ainda avaliado o uso da biomassa seca como agente pigmentante em um material polimérico. Foram isoladas sete colônias pigmentadas (4 do solo, 2 de água e 1 de fruto), as quais foram identificadas como pertencentes ao gênero Rhodotorula. Com relação as cascas de mandioca, o principal componente em $\% \mathrm{~m} / \mathrm{m}$ foi o amido $(71,0)$, seguido da lignina $(13,0)$, glucana $(4,6)$, xilana $(2,4)$, cinzas $(2,6)$ e extrativos $(4,6)$. Na melhor condição de hidrólise ácida ( $1 \% \mathrm{H}_{2} \mathrm{SO}_{4}, 10 \%$ sólidos, $\left.120 \mathrm{~min}\right)$, foi obtido $48 \mathrm{~g} / \mathrm{L}$ de glicose, o que correspondeu a uma eficiência de $67 \%$. Já para a hidrólise enzimática (3000 U Termamyl 2X, 240 U AMG XXL, 14\% sólidos, 65 min) obtevese $80,8 \mathrm{~g} / \mathrm{L}$ de glicose, correspondendo a uma eficiência de $79,5 \%$. Nas condições de cultivo empregando HA ou HE contendo cerca de $50,0 \mathrm{~g} / \mathrm{L}$ de glicose sem qualquer suplementação $\left(\mathrm{pH}\right.$ inicial 6,0, temperatura de $30^{\circ} \mathrm{C}$, agitação de $200 \mathrm{rpm}$ e na presença de luminosidade) foi possível selecionar a cepa Rh S2 no HA e a Rh RNA no HE, as quais apresentaram, respectivamente $(12,7 \mathrm{~g} / \mathrm{L}$ e $7,6 \mathrm{mg} / \mathrm{L})$ e $(22,8$ $\mathrm{g} / \mathrm{L}$ e $11,2 \mathrm{mg} / \mathrm{L}$ ) de biomassa e carotenoides totais. O maior potencial antioxidante foi obtido com a cepa Rh S2 que apresentou cerca de $30 \%$ de redução do radical DPPH sendo que ambos extratos apresentaram ação anti-microbiana frente à Escherichia coli e Aspergillus fumigatus. Quanto as propriedades mecânicas do compósito formulado com a biomassa seca da cepa Rh S2, ficou demonstrada a possibilidade do uso desta biomassa como agente pigmentante em resinas poliméricas. Estes resultados revelam 0 grande potencial das leveduras selecionadas para a produção de carotenoides a partir de um subproduto da agroindústria, ressaltando ainda suas importantes propriedades biológicas e de pigmentação, as quais poderão ser exploradas em diferentes aplicações.

Palavras-chaves: Leveduras. Pigmentos carotenoides. Casca de mandioca. Vitamina A e anti-oxidante. 


\section{ABSTRACT}

TORRES, D. R. Utilization of the cassava peel hydrolyzate as a substrate for the production of carotenoids by yeasts isolated from the Amazon Region. 2019. 174 p. Thesis (Doctor of Science) - Escola de Engenharia de Lorena, Universidade de São Paulo, Lorena, 2019.

The present work had as objective the utilization of the hydrolyzate of cassava peels for the production of carotenoid pigments. For this, the yeast from the Amazon region was isolated, characterizing the cassava peels and acid hydrolysates (HA) and enzymatic $(\mathrm{HE})$. Finally, the effect of the $\mathrm{C}$ : $\mathrm{N}$ ratio and the luminosity on carotenoid production by the selected yeasts in the hydrolysates were evaluated. Carotenogens extracts are characterized as antioxidant and antimicrobial potential, and the use of dry biomass as a pigment agent in a polymeric material is also evaluated. Seven pigmented colonies (4 soil, 2 water and 1 fruit) were isolated, as were the communities as individuals belonging to the genus Rhodotorula. Compared with cassava peels, the main component in\% by weight of starch (71.0), followed by lignin (13.0), glucan (4.6), xylan (2.4), ashes (26) and extractives (4.6). The acid hydrolysis condition ( $1 \% \mathrm{H} 2 \mathrm{SO} 4,10 \%$ solids, $120 \mathrm{~min}$ ) was $48 \mathrm{~g} / \mathrm{L}$ glucose, corresponding to an efficiency of $67 \%$. Already for an enzymatic hydration (3000 U Termamyl 2X, 240 U AMG XXL, 14\% solids, $65 \mathrm{~min}$ ), $80.8 \mathrm{~g} / \mathrm{L}$ of glucose was obtained, corresponding to an efficiency of $79.5 \%$. In the ingestion conditions using $\mathrm{HA}$ or $\mathrm{HE}$ of about $50.0 \mathrm{~g} / \mathrm{L}$ of glucose without any supplement (initial $\mathrm{pH} 6.0$, temperature of $30^{\circ} \mathrm{C}$, agitation of the presence light) it was possible to select the strain Rh S2 in HA and Rh RNA is not HE, as it is today $(12.7 \mathrm{~g} / \mathrm{L}$ and $7.6 \mathrm{mg} / \mathrm{L})$ and $(22.8 \mathrm{~g} / \mathrm{L}$ and $11.2 \mathrm{mg} / \mathrm{L})$ biomass and total carotenoids. The highest antioxidant potential was obtained with the Rh S2 protein which had about $30 \%$ reduction of the DPPH radical, with both extracts being moved against the microbiota against Escherichia coli and Aspergillus fumigatus. Regarding the mechanical properties of the compound formulated with a dry biomass of the strain Rh S2, the possibility of the use of this biomass as pigment agent in polymer resins has been demonstrated. This research was useful to increase the potential of selected yeasts for the production of carotenoids from a by-product of agroindustry, highlighting their historical and pigmentation characteristics, such as the ports explored in different applications.

Keywords: Yeasts. Carotenoid pigments. Cassava peel. Vitamin A and antioxidant. 